\title{
NATURAL DURABILITY ASSESSMENT OF THERMO-MODIFIED YOUNG WOOD OF Eucalyptus
}

\author{
Sofia Knapic ${ }^{1, \leadsto}$, Joana Santos ${ }^{2}$, José Santos $^{2}$, Helena Pereira ${ }^{1}$
}

In memoriam of Dr. Thomas C. MANNES

\begin{abstract}
This study focuses on the effect on wood strength and natural durability of Eucalyptus globulus and Eucalyptus botryoides when subjected to heat treatments with low energy consumption. The objective was to improve the wood durability, without negatively impacting the strength properties. Six-year-old trees from Eucalyptus globulus and Eucalyptus botryoides were used.

The samples were heat treated for $4 \mathrm{~h}$ conditioned to very low oxygen availability. A field test for assessing the resistance to termites and fungal degradation was conducted according to EN 252:1989/ AC1:1989 Inspections were made every six months for 3 years. All the samples of Eucalyptus globulus showed signs of termite and microorganisms attack, most showing extensive galleries. Eucalyptus botryoides wood showed no sign of termite attack and only few traces of microrganisms presence. The wood bending strength was smaller upon thermal treatment for both species, decreasing $3.8 \%$ and $4.8 \%$ for Eucalyptus globulus and Eucalyptus botryoides, respectively. Overall the results are promising regarding some common utilizations, mainly floor coverings, decks, doors and door and window frames, fences (only for Eucalyptus botryoides), decorative arbors and pergolas (only for Eucalyptus botryoides) but excluding structural beams for building roofs or bridges due to the fragility of the wood treated thermally towards impacts.
\end{abstract}

Keywords: Eucalyptus botryoides, Eucalyptus globulus, mechanical properties, shrinkage, termites, wood degradation.

\section{INTRODUCTION}

Wood is a biological material vulnerable to several biotic agents such as fungal degradation and termite attacks that are a major threat to the service-life of wood. Wood durability depends on species, heartwood and sapwood distribution, chemical composition e.g. extractives and lignin content and composition, density, moisture content, and conditions of use (Panshin and de Zeew 1980). The servicelife of wood products depends primarily on the specific wood durability (Kollmann and Côté 1984). However, the determination of characteristic strong timbers or the utilization of additive treated wood segments are affected by cost and end-utilize prerequisites (e.g. measurements).

Termites are one of the most successful groups of insects that feed on dead plant material and cellulose, generally in the form of wood, leaf litter, soil, or animal dung (Cruz et al. 2015). Various woods differ in their susceptibility to termite attack; the differences are attributed to factors such as moisture content, hardness, and resin and lignin content (Cruz et al. 2015). Important biological

${ }^{1}$ Centro de Estudos Florestais, Instituto Superior de Agronomia, Universidade de Lisboa, Lisboa, Portugal.

${ }^{2}$ Laboratório Nacional de Energia e Geologia, Lisboa, Portugal.

•Corresponding author: sknapic@isa.ulisboa.pt

Received: 19.07.2017 Accepted: 08.03.2018 
attacks that may strongly impact wood in-use performance result from termites. When feeding on wood, termites compromise the mechanical and physical properties. The durability of various tropical timbers feeding termite attacks was assessed in several studies (Arango et al. 2006, Peralta et al. 2004, Takamura 2001, Tsunoda 1990). A positive relationship was found between specimen dimension and natural resistance (Antwi-Boasiako and Allotey 2010), and wood resistance in ground contact was proportional to its thickness (Trada 1984).

Several treatments have been investigated to increase the wood resistance against termites. For example, application of waxes and paraffin impregnation (Esteves et al. 2014, Lesar and Humar 2010, Scholz et al. 2010), and wood smoking (Hadi et al. 2010) showed dependence of termite resistance on the type and intensity of treatments e.g. wood smoking had no effect on resistance. A recent study on termite resistance of pine wood treated with zinc- and copper-based nanocompounds showed a strong inhibition of termite feeding (Mantanis et al. 2014). Acetylated radiata pine and furfurylated Southern yellow pine were tested against Mediterranean termites and these two wood modification processes were considered as alternative preventive treatments (Gascón-Garrido et al. 2013).

The thermal treatment is also a wood modification method that improves dimensional stability, decreases hygroscopicity, and enhances durability except when in direct contact with the soil (Esteves et al. 2007, Nguyen et al. 2012).

Heat treatment of wood changes its chemical composition by altering cell wall compounds and extractives leading to mass loss, and also affects the anatomical structure of wood and its physical properties (Esteves et al. 2008, Esteves et al. 2007). Wood colour is also altered by darkening and becomes uniform throughout the thickness of wood (Esteves et al. 2008, Guller 2012). Research on wood thermal modifications is quite active and several wood species and treatment conditions have been studied (Araújo et al. 2016, Doi et al. 1999, Esteves and Pereira 2009, Manabendra et al. 2002).

The thermal treatment of wood has been successfully applied by the wood industry (Zhang et al. 2013), and Guller (2012) reports that there are 30 companies operating across Europe, mainly in Finland (40\%), Germany (13\%), Netherlands (12\%) and Estonia (8\%). The thermally treated wood is applied for exterior uses such as decks, fences, garden furniture, doors and windows and for interior uses like kitchen furniture, parquet and panels (Esteves et al. 2007).

Eucalypt species have been increasingly considered for thermal treatments aiming at their use for high quality solid wood products because they have high mechanical performances, few knots and are suitable for glued joints. e.g. E. grandis (Bal et al. 2013), E. globulus (Esteves et al. 2007, Santos 2000). E. globulus presents a slow and difficult drying process with low dimensional stability (Santos 2000) and the heat treatment allowed improvements regarding a decreased moisture equilibrium and surface wettability, and an increased dimensional stability (Esteves et al. 2007). Thermally treated wood of E. botryoides also showed an increase in dimensional stability (Delucis et al. 2014) as well as several tropical species (Araújo et al. 2016).

This study analyses the effect on wood natural durability and strength of Eucalyptus globulus and Eucalyptus botryoides, when subjected to heat treatments with low energy consumption.

The objective is to improve the wood quality of these two eucalypt species regarding durability, but without negatively impacting the strength properties.

\section{MATERIALS AND METHODS}

For this study, 6-year-old trees from E. globulus (heartwood and sapwood) and E. botryoides were used. The trees were grown in rows with $3 \mathrm{mx} 3 \mathrm{~m}$ spacing (without fertilization) on an experimental site located in the campus fields of the School of Agriculture, University of Lisbon (ULisboa), at Tapada da Ajuda, Lisboa, Portugal $\left(38^{\circ} 42^{\prime} \mathrm{N} ; 09^{\circ} 10^{\prime} \mathrm{W}\right)$. The trees were cut into small logs (0,5 m length) of which samples were taken according to standard demands.

The wood samples were air-dried by conventional methods until below 13\% moisture content. 
Wood boards were cut to $30 \mathrm{~mm}$ thickness, $200 \mathrm{~mm}$ width and $400 \mathrm{~mm}$ length. The samples were introduced in a metallic box that was filled with wood pieces of other dimensions in order to obtain an almost full space occupation, and the remaining space filled with an inert material (fine sand) (Santos et al. 2016) assuring a maximum of $2 \%$ oxygen content. The box was closed by an appropriate cover and introduced in the laboratorial oven provided with internal ventilation. The treatment was done at $210{ }^{\circ} \mathrm{C}$ during $4 \mathrm{~h}$ in a closed atmosphere (with the temperature inside the box rising previously at a rate of approximately $50^{\circ} \mathrm{C}$ per h), conditioned to very low oxygen availability (Santos et al. 2016). For wood to not combust, it is necessary to condition the surrounding environment, preventing the arrival of oxygen, which is achieved in this invention by immersing the wood in a medium consisting of solid particles, very fine sand, mixed or not with reducing agents which preferentially consume the available oxygen.

The thermally treated and the non-treated board samples (containing only sapwood) were cut to the specific dimensions required by the physical and mechanical tests (modulus of elasticity, bending strength, tangential and radial shrinkage, and density) according to BS 373, EN 408, EN 1910, and IPQ-NP 616-1973 and the natural durability assessment tests following the "Field test method for determining the relative protective effectiveness of a wood preservative in ground contact" (EN 252). The field (Figure 1) was located in the campus of the School of Agriculture; the region is under the influence of a meso-thermal humid climate, with a dry season in the summer extending from June to August, and registering above $10^{\circ} \mathrm{C}$ in the coldest month and below or equal to $22^{\circ} \mathrm{C}$ in the hottest month, and the soil is a Vertisol characterized by a fine, or medium to fine, texture, derived from tuffs or basalts, frequently with limestone on the inferior horizons, or from calcareous rock (in much less extension). No studies were made to establish the species of termites present in the field. The wood stakes, with $500 \pm 1 \mathrm{~mm} \times 80 \pm 0,3 \mathrm{~mm} \times 25 \pm 0,3 \mathrm{~mm}$ (axial, tangential, radial), were inserted vertically to half their length in the soil (Figure 1). The distribution of the wood samples per species was made randomly.
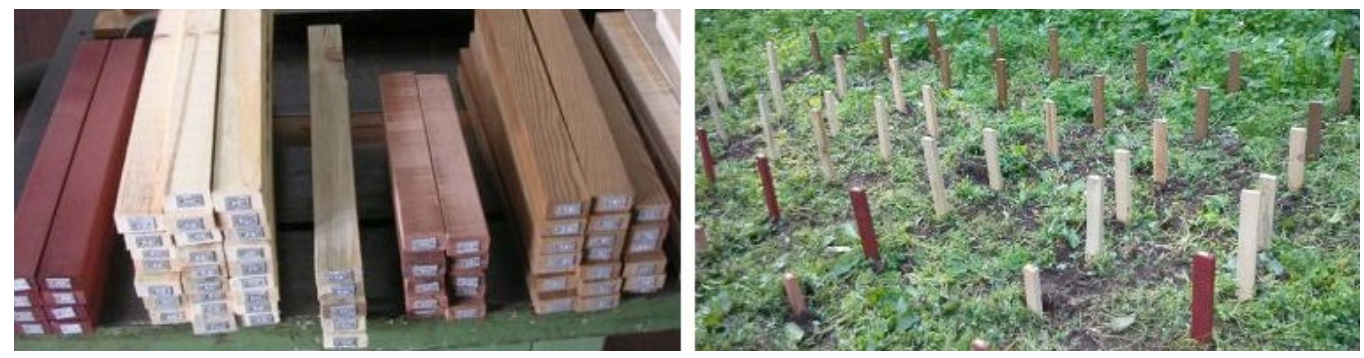

Figure 1. Field test for wood durability: preparation of the samples (left); samples placed in the ground according to EN 252:1989/AC1:1989 specifications.

Inspections were made every six months, and the results in this paper contemplate inspections made at $6,12,18$ and 36 months. On each inspection, the stakes were removed from the ground, cleaned, and a visual classification was conducted with images of the wood stakes recorded to register signs of termite and microorganisms attack. Table 1 displays the standard rating system. After examination, the stakes were re-installed in the ground taking in the same positions.

Table 1. Rating system for the visual classification inspection (EN 252).

\begin{tabular}{|c|l|l|}
\hline Class & Class Designation & Features \\
\hline 0 & No attack & No signs \\
\hline 1 & Mild attack & Superficial signs of attack \\
\hline 2 & Medium attack & Attack signs to 2 to $5 \mathrm{~mm}$ depth \\
\hline 3 & Severe attack & $\begin{array}{l}\text { Attack signs with } 4 \text { to } 10 \mathrm{~mm} \text { depth } \\
\text { with interior galleries }\end{array}$ \\
\hline 4 & Rupture & Total penetration or destruction \\
\hline
\end{tabular}


Mechanical testing was made using a Shimadzu AG-I universal machine type 250, with a $250 \mathrm{kN}$ force sensor. The bending strength and modulus of elasticity were determined in agreement with the standard IPQ-NP 619-1973.

\section{RESULTS AND DISCUSSION}

Table 2 presents the results on wood properties of untreated and thermally treated E. globulus and $E$. botryoides bending modulus of elasticity (MOE), modulus of rupture (MOR), radial and tangential shrinkage, and density. Density decreased in the thermally treated samples by $9 \%$ for E. globulus and $7 \%$ for $E$. botryoides. The heat-treated wood showed a decrease of radial and tangential shrinkage, for both species but the difference was higher for E. botryoides, especially for the tangential shrinkage. MOE and MOR were affected by the thermal treatment. This behaviour is consistent with former results obtained for E. globulus (Esteves et al. 2007).

Table 2. Wood properties of untreated and thermally treated E. globulus and E. botryoides.

\begin{tabular}{|l|c|c|c|c|}
\hline & \multicolumn{2}{|c|}{ Eucalyptus globulus } & \multicolumn{2}{c|}{ Eucalyptus botryoides } \\
\hline & Natural & Thermally treated & Natural & Thermally treated \\
\hline Tangential shrinkage (\%) & 16,7 & 12,4 & 13,0 & 4,7 \\
\hline Radial shrinkage (\%) & 7,5 & 6,2 & 6,4 & 2,6 \\
\hline MOE $(\mathrm{MPa})$ & 13909 & 13379 & 11021 & 10488 \\
\hline MOR $(\mathrm{MPa})$ & 111 & 102 & 100 & 82 \\
\hline Density $\left(\mathrm{kg} \cdot \mathrm{m}^{-3}\right)$ & 732 & 664 & 821 & 765 \\
\hline
\end{tabular}

Overall MOE was less affected by the heat treatment than MOR, which is in accordance with Bengtsson et al. (2002) and Esteves et al. (2007). E. globulus showed a MOE decrease of 4\%. Studies with E. globulus found that MOE decreased 5\% until $8 \%$ mass loss and $15 \%$ for a $13 \%$ mass loss (Esteves et al. 2007), and similar results were found for E. saligna (Vital et al. 1983). Contrary to these results $E$. botryoides showed an increase of 4\%, a tendency supported by Santos (2000) who reported an increase in MOE using E. globulus.

The wood bending strength was smaller upon thermal treatment for both species, decreasing 3,8\% and $4,8 \%$ for E. globulus and E. botryoides, respectively. These values are in accordance with studies for E. globulus (Esteves et al. 2007).

Figure 2 and Figure 3 display images of the samples after 36 months of ground contact. The termite damage was characterized by the occurrence of channels excavated inside the wood stakes, whereas the attack by microorganisms was shown by the presence of spots and stains (white or green). The decay was confirmed visually.

All the samples of E. globulus showed signs of termite and microorganisms attack, some with extensive galleries (Figure 2). After 36 months exposure, $10 \%$ of E. globulus stakes showed severe attack and $90 \%$ were totally destroyed (Table 3). Hence, E. globulus stakes were classified as susceptible to termites or microorganisms (severe attack and rupture according to the rating system for the visual classification inspection for termite attack displayed on Table 1). On the other hand, $E$. botryoides showed no sign of termite attack and only few traces of microorganisms' presence (Figure 3 ). Hence, E. botryoides stakes were classified as not susceptible to termites or microorganisms (no attack and rupture according to the rating system for the visual classification inspection for termite attack displayed on Table 1). 


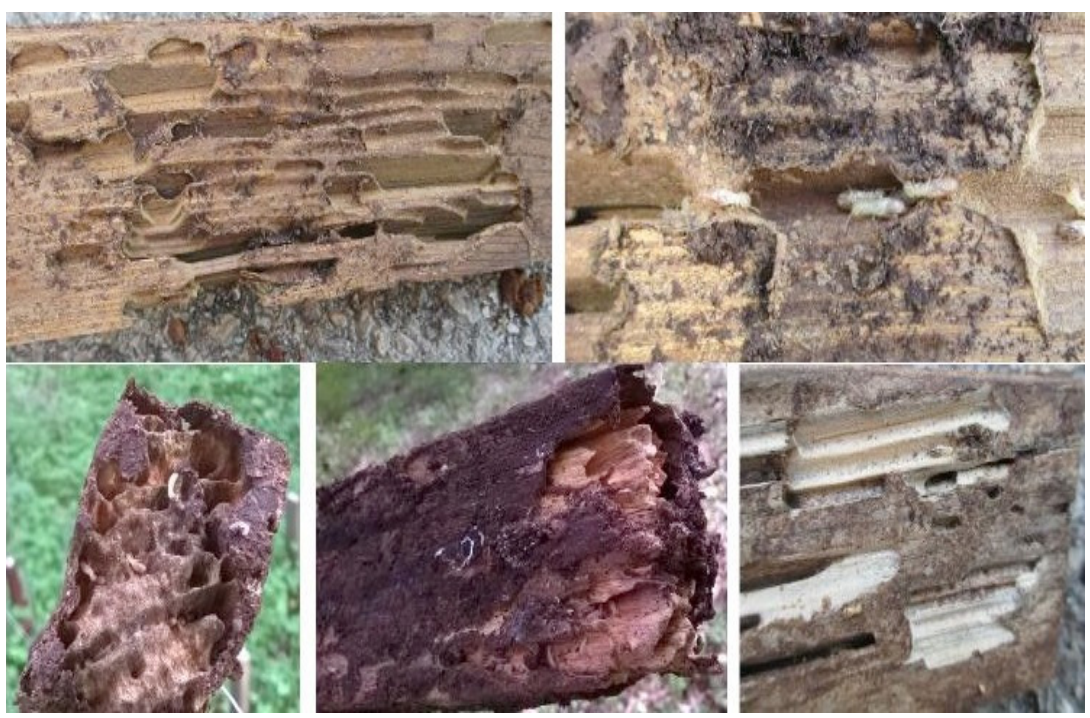

Figure 2. E. globulus wood: images of the samples after ground contact.
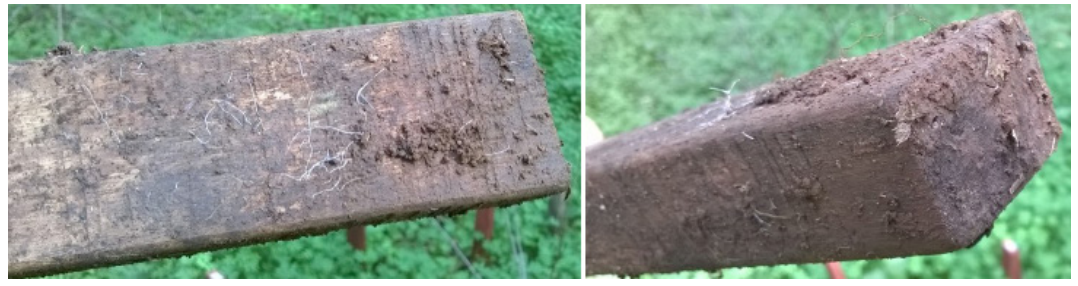

Figure 3. E.botryoides wood: images of the samples after ground contact.

The results for E. globulus were similar to the ones obtained with E. grandis also showing grooving channels inside the wood (Ncube et al. 2012) with the classification of slightly durable that lead the authors to advise the impregnation of $E$. grandis wood with preservatives. Other studies with $E$. grandis showed a low to moderate natural durability on thermally treated wood (Batista et al. 2016, Pessoa et al. 2006, Silva et al. 2006). 
Table 3. Comparative results ( $\%$ of samples in different classes) of termite and microorganisms attack in field test, after 6, 12, 18 and 36 months exposure.

\begin{tabular}{|c|c|c|c|c|c|c|}
\hline & $\begin{array}{c}\text { Time in field } \\
\text { test }\end{array}$ & Sound & $\begin{array}{l}\text { Slight } \\
\text { attack }\end{array}$ & $\begin{array}{l}\text { Moderate } \\
\text { attack }\end{array}$ & $\begin{array}{l}\text { Severe } \\
\text { attack }\end{array}$ & Rupture \\
\hline \multicolumn{7}{|l|}{ Termites attack } \\
\hline \multirow{4}{*}{$\begin{array}{l}\text { Eucalyptus globulus } \\
\text { (natural) }\end{array}$} & 6 months & $45 \%$ & $55 \%$ & $0 \%$ & $0 \%$ & $0 \%$ \\
\hline & 12 months & $20 \%$ & $70 \%$ & $10 \%$ & $0 \%$ & $0 \%$ \\
\hline & 18 months & $0 \%$ & $0 \%$ & $35 \%$ & $55 \%$ & $10 \%$ \\
\hline & 36 months & $0 \%$ & $0 \%$ & $0 \%$ & $0 \%$ & $100 \%$ \\
\hline \multirow{4}{*}{$\begin{array}{l}\text { Eucalyptus globulus } \\
\text { (thermally treated) }\end{array}$} & 6 months & $88 \%$ & $12 \%$ & $0 \%$ & $0 \%$ & $0 \%$ \\
\hline & 12 months & $38 \%$ & $63 \%$ & $0 \%$ & $0 \%$ & $0 \%$ \\
\hline & 18 months & $25 \%$ & $25 \%$ & $0 \%$ & $25 \%$ & $25 \%$ \\
\hline & 36 months & $0 \%$ & $0 \%$ & $0 \%$ & $10 \%$ & $90 \%$ \\
\hline \multirow{4}{*}{$\begin{array}{l}\text { Eucalyptus botryoides } \\
\text { (natural) }\end{array}$} & 6 months & $100 \%$ & $0 \%$ & $0 \%$ & $0 \%$ & $0 \%$ \\
\hline & 12 months & $100 \%$ & $0 \%$ & $0 \%$ & $0 \%$ & $0 \%$ \\
\hline & 18 months & $100 \%$ & $0 \%$ & $0 \%$ & $0 \%$ & $0 \%$ \\
\hline & 36 months & $100 \%$ & $0 \%$ & $0 \%$ & $0 \%$ & $0 \%$ \\
\hline \multirow{4}{*}{$\begin{array}{l}\text { Eucalyptus botryoides } \\
\text { (thermally treated) }\end{array}$} & 6 months & $100 \%$ & $0 \%$ & $0 \%$ & $0 \%$ & $0 \%$ \\
\hline & 12 months & $100 \%$ & $0 \%$ & $0 \%$ & $0 \%$ & $0 \%$ \\
\hline & 18 months & $100 \%$ & $0 \%$ & $0 \%$ & $0 \%$ & $0 \%$ \\
\hline & 36 months & $100 \%$ & $0 \%$ & $0 \%$ & $0 \%$ & $0 \%$ \\
\hline \multicolumn{7}{|l|}{$\begin{array}{c}\text { Microorganisms } \\
\text { attack }\end{array}$} \\
\hline \multirow{4}{*}{$\begin{array}{l}\text { Eucalyptus globulus } \\
\text { (natural) }\end{array}$} & 6 months & $90 \%$ & $10 \%$ & $0 \%$ & $0 \%$ & $0 \%$ \\
\hline & 12 months & $60 \%$ & $30 \%$ & $10 \%$ & $0 \%$ & $0 \%$ \\
\hline & 18 months & $0 \%$ & $80 \%$ & $20 \%$ & $0 \%$ & $0 \%$ \\
\hline & 36 months & $0 \%$ & $0 \%$ & $80 \%$ & $20 \%$ & $0 \%$ \\
\hline \multirow{4}{*}{$\begin{array}{l}\text { Eucalyptus globulus } \\
\text { (thermally treated) }\end{array}$} & 6 months & $100 \%$ & $0 \%$ & $0 \%$ & $0 \%$ & $0 \%$ \\
\hline & 12 months & $50 \%$ & $50 \%$ & $0 \%$ & $0 \%$ & $0 \%$ \\
\hline & 18 months & $0 \%$ & $75 \%$ & $25 \%$ & $0 \%$ & $0 \%$ \\
\hline & 36 months & $0 \%$ & $0 \%$ & $80 \%$ & $20 \%$ & $0 \%$ \\
\hline \multirow{4}{*}{$\begin{array}{l}\text { Eucalyptus botryoides } \\
\text { (natural) }\end{array}$} & 6 months & $95 \%$ & $5 \%$ & $0 \%$ & $0 \%$ & $0 \%$ \\
\hline & 12 months & $90 \%$ & $10 \%$ & $0 \%$ & $0 \%$ & $0 \%$ \\
\hline & 18 months & $55 \%$ & $45 \%$ & $0 \%$ & $0 \%$ & $0 \%$ \\
\hline & 36 months & $50 \%$ & $40 \%$ & $5 \%$ & $0 \%$ & $0 \%$ \\
\hline \multirow{4}{*}{$\begin{array}{l}\text { Eucalyptus botryoides } \\
\text { (thermally treated) }\end{array}$} & 6 months & $100 \%$ & $0 \%$ & $0 \%$ & $0 \%$ & $0 \%$ \\
\hline & 12 months & $100 \%$ & $0 \%$ & $0 \%$ & $0 \%$ & $0 \%$ \\
\hline & 18 months & $60 \%$ & $40 \%$ & $0 \%$ & $0 \%$ & $0 \%$ \\
\hline & 36 months & $60 \%$ & $40 \%$ & $0 \%$ & $0 \%$ & $0 \%$ \\
\hline
\end{tabular}


A study on natural durability against basidiomycetes and the wood-boring insect using $E$. grandis and Eucalyptus $x$ trabutii (according to EN335-1), showed promising results for the latest (Palanti et al. 2010). A study on the termite resistance of wood species grown in Hawaii showed that E. microcorys was very resistant, E. robusta slightly resistant and E. deglupta very susceptible (Grace et al. 1996).

Comparative studies on the in-ground and above-ground durability of European oak heartwood were made using also EN 252 (Brischke et al. 2009). Quercus robur ranged from slightly durable to non-durable and Quercus petraea was classified as non-durable.

Overall the results of this study indicate a need to increase the duration of the treatment since the difference in values for physical properties is not as significant as in other species subjected to the same treatment.

\section{CONCLUSIONS}

The main conclusion is that, in general, the thermal treatments administrated in this study are not an effective process for increasing natural durability of wood when in direct contact to the ground.

Nevertheless, the values for the studied properties of thermally treated wood of E. Globulus and $E$. botryoides point towards potential promising utilizations mainly for floor coverings, decks, doors and door and window frames. Additionally, the use of thermally treated E. botryoides wood can also be considered for outdoor and in-ground contact uses such as fences and decorative arbors and pergolas.

However, it is not advisable to apply this wood for structural purposes due to the fragility of the thermally treated wood towards impacts.

The high durability of E. botryoides towards termite attack is probably due to its chemical composition, something that should be addressed in a future study.

\section{ACKNOWLEDGMENTS}

This study was funded by project EucPlus - New processes and uses for eucalypt woods (PTDC/ AGR-CFL/119752/2010) by FCT (Fundação para a Ciência e a Tecnologia, Portugal). Centro de Estudos Florestais is a research unit supported by the national funding of FCT (UID/AGR/00239/2013). Funding from FCT is acknowledged by the first author with a post-doctoral grant (SFRH/BPD/76101/2011).

\section{REFERENCES}

Arango, R.A.; Green III, F.; Hintz, K.; Lebow, P.K.; Miller, R.B. 2006. Natural durability of tropical and native woods against termite damage by Reticulitermes flavipes (Kollar). International Biodeterioration \& Biodegradation 57 (3): 146-150.

Araújo, S.O.; Vital, B.R.; Oliveira, B.; Carneiro, A.C.O.; Lourenço, A.; Pereira, H. 2016. Physical and mechanical properties of heat treated wood from Aspidosperma populifolium, Dipteryx odorata and Mimosa scabrella. Maderas-Cienc Tecnol 18(1): 143-156.

Antwi-Boasiako, C.; Allotey, A. 2010. The effect of stake dimension on the field performance of two hardwoods with different durability classes. International Biodeterioration \& Biodegradation 64: 267-273. 
Bal, B.C.; Bektaş, I. 2013. The Effects of Heat Treatment on Some Mechanical Properties of Juvenile Wood and Mature Wood of Eucalyptus grandis. Drying Technology 31(4): 479-485.

Batista, D.C.; Nisgoski, S.; Oliveira, J.T.S.; Muñiz, G.I.B.; Paes, J.B. 2016. Resistance of thermally modified Eucalyptus grandis W. Hill ex Maiden wood to deterioration by dry-wood termites (Cryptotermes sp.). Ciência Florestal 26 (2): 671-678.

Bengtsson, C.; Jermer, J.; Brem, F. 2002. Bending strength of heat-treated spruce and pine timber. In: International Research Group Wood Pre, section 4 - Processes, NIRG/WP 02-40242.

Brischke, C.; Welzbacher, C.R.; Rapp, A.O.; Augusta, U.; Brandt, K. 2009. Comparative studies on the in-ground and above-ground durability of European oak heartwood (Quercus petraea Liebl. and Quercus robur L.). European Journal of Wood Products 67: 329-338.

Cruz, H.; Jones, D.; Nunes, L. 2015. Wood. In Materials for Construction and Civil Engineering. M.C. Gonçalves, F. Margarido (eds.), Springer International Publishing Switzerland. pp. 557-583.

Delucis, R.A.; Gatto, D.A.; Cademartori, P.H.G.; Missio, A.L.; Schneid, E. 2014. Physical properties of four thermally treated hardwoods. Floresta e Ambiente 21(1): 99-107.

Doi, S.; Kurimoto, Y.; Ohmura, W.; Ohara, S.; Aoyama, M.; Yoshimura, T. 1999. effects of heat treatments of wood on the feeding behaviour of two subterranean termites. Holzforschung 53: 225-229.

EN 335-1. 2006. Durability of wood and wood-based products. Definition of use classes. Part 1: General.

Esteves, B.; Nunes, L.; Domingos, I.; Pereira, H. 2014. Improvement of termite resistance, dimensional stability and mechanical properties of pine wood by paraffin impregnation. European Journal of Wood and Wood Products 72: 609-615.

Esteves, B.M.; Domingos, I.J.; Pereira, H.M. 2007. Pine wood modification by heat treatment in air. BioResources 3(1): 1-5.

Esteves, B.M.; Marques, A.V.; Domingos, I.; Pereira, H. 2008. Heat-induced colour changes of pine (Pinus pinaster) and eucalypt (Eucalyptus globulus) wood. Wood Science and Technology 42: 369-384.

Esteves, B.M.; Pereira, H.M. 2009. Wood modification by heat treatment: A review. BioResources 4 (1): 370-404.

European Standard. EN. 1989. Field test method for determining the relative protective effectiveness of wood preservatives in ground contact. Inspection and evaluation of the attack of stakes caused by microorganisms. CEN. EN 252.1989.

European Standard. EN. 2003. Timber structures - Structural timber and glued laminated timber - Determination of some physical and mechanical properties. EN 408. 2003

European Standard. EN. 2000. Wood and parquet flooring and wood panelling and cladding determination of dimensional stability. EN 1910. 2000. CEN.

Gascón-Garrido, P.; Oliver-Villanueva, J.V.; Ibiza-Palacios, M.S.; Militz, H.; Mai, C.; Adamopoulos, S. 2013. Resistance of wood modified with different technologies against Mediterranean termites (Reticulitermes spp.). International Biodeterioration \& Biodegradation 82: 13-16.

Grace, J.K.; Ewart, D.M.; Tome, C.H.M. 1996. Termite resistance of wood species grown in Hawaii. Solid Wood Products 46 (10): 57-60.

Guller, B. 2012. Effects of heat treatment on density, dimensional stability and color of Pinus nigra wood. African Journal of Biotechnology 11 (9): 2204-2209. 
Hadi, Y.S.; Nurhayati, T.; Jasni, J.; Yamamoto, H.; Kamiya, N. 2010. Smoked Wood as an Alternative for Wood Protection against Termites. Forest Products Journal 60 (6): 496-500.

IPQ STANDARD NP. 1973. Madeiras - Determinação da massa volúmica. IPQ-NP 616. 1973.

IPQ STANDARD NP. 1973. Madeiras - Ensaio de flexão estática. IPQ-NP 619. 1973.

Kollmann, F.F.P.; Côté JR, W.A. 1984. Principles of Wood Science and Technology. In: Solid Wood, vol. 1. Springer-Verlag OHG, Berlin, Heidelberg, New York/Tokyo.

Lesar, B.; Humar, M. 2010. Use of wax emulsions for improvement of wood durability and sorption properties. European Journal of Wood and Wood Products 69: 231-238.

Manabendra, D.; Saikia, C.N.; Baruah, K.K. 2002. Studies on thermal degradation and termite resistant properties of chemically modified wood. Bioresource Technology 84 (2): 151-157.

Mantanis, G.; Terzi, E.; Kartal, S.N.; Papadopoulos, A.N. 2014. Evaluation of mold, decay and termite resistance of pine wood treated with zinc- and copper-based nanocompounds. International Biodeterioration \& Biodegradation 90: 140-144.

Ncube, E.; Chungu, D.; Kamdem, D.P.; Musawa, K. 2012. Use of a short span field test to evaluate termite resistance of Eucalyptus grandis and Bobgunnia madagascariensis in a tropical environment. BioResources 7 (3): 4098-4108.

Nguyen, C.T.; Wagenführ, A.; Phuong LE, X.; Dai, V.H.; Bremer, M.; Fischer, S. 2012. The effects of thermal modification on the properties of two Vietnamese Bamboo species, part I: effects on physical properties. BioResources 7 (4): 5355-5366.

Palanti, S.; Susco, D.; Fec, I.E. 2010. Natural durability of eucalypt from Italian plantations against fungiand cerambicid Trichoferus holosericeus Rossi. European Journal of Wood and Wood Products 68: 59-62.

Panshin, A.; De Zeew, C. 1980. Textbook of Wood Technology. Structure, Identification, Properties and Uses of the Commercial Woods of the United States and Canada. Fourth ed. McGraw-Hill, Inc, New York, USA.

Peralta, R.C.G.; Menezes, E.B.; Carvalho, A.G.; Aguiar-Menezes, E.L. 2004. Wood consumption rates of forest species by subterranean Termites (isoptera) under field conditions. Árvore 28: $283-289$.

Pessoa, A.M.C.; Berti-Filho, E.; Brito, J.O. 2006. Avaliação da madeira termorretificada de Eucalyptus grandis, submetida ao ataque de cupim de madeira seca, Cryptotermes brevis [Evaluation of the Eucalyptus grandis thermorectificated wood submitted to the drywood termite attack, Cryptotermes brevis]. Scientia Forestalis 72: 11-16.

Santos, J.A. 2000. Mechanical behaviour of Eucalyptus wood modified by heat. Wood Science and Technology 34 (1): 39-43.

Santos, J.A.; Knapic, S.; Pereira , H. 2016. Processo de modificação térmica da madeira em leito

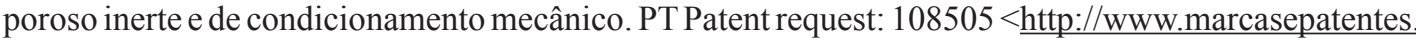
pt/files/collections/pt_PT/49/55/573/604/2016-11-28.pdf $>$

Scholz, G.; Militz, H.; Gascón-Garrido, P.; Ibiza-Palacios, M.S.; Oliver-Villanueva, J.V.; Peters, B.C.; Fitzgerald, C.J. 2010. Improved termite resistance of wood by wax impregnation. International Biodeterioration \& Biodegradation 64: 688-693.

Silva, J.C.; Oliveira, J.T.S.; Xavier, B.A.; Castro, V.R. 2006. Variação da retratibilidade da madeira de Eucalyptus grandis Hill ex Maiden, em função da idade e posição radial no tronco. Árvore 30 (5): 803-810. 
Takamura, K. 2001. Effects of Termite Exclusion on Decay of Heavy and Light Hardwood in a Tropical Rain Forest of Peninsular Malaysia. Journal of Tropical Ecology 17 (4): 541-548.

Trada. 1984. Timber Pests and Their Control. Timber Research and Development Association (TRADA). Executive Press Limited, Burnham. Bucks. England.

Tsunoda, K. 1990. The Natural Resistance of Tropical Woods against Biodeterioration. Wood Research 77: 18-27.

Vital, B.; Lucia, R.; Della, R.; Euclides, R. 1983. Effect of heating on some properties of Eucalyptus saligna wood. Árvore 7 (2): 136-146.

Zhang, Y.M.; Yu, Y.L.; Yu, W.J. 2013. Effect of termal treatment on the physical and mechanical properties of phyllostachys pubescen bamboo. European Journal of Wood and Wood Products 71 (1): 61-67. 